\title{
Nomenclature, variation, and the biological species concept in Lamasina (Lycaenidae: Theclinae: Eumaeini)
}

\author{
Robert K. Robbins ${ }^{1} \&$ Gerardo Lamas ${ }^{2}$ \\ ${ }^{1}$ Department of Entomology, Smithsonian Institution. PO Box 37012, NHB Stop 105, Washington, DC 20013-7012 USA. \\ E-mail: robbinsr@si.edu \\ ${ }^{2}$ Museo de Historia Natural, Universidad Nacional Mayor de San Marcos. Apartado 14-0434, Lima-14, Peru. \\ E-mail: glamasm@unmsm.edu.pe
}

\begin{abstract}
The correct generic name for the species that belong to Eucharia Boisduval, 1870, a homonym, is either Annamaria D'Abrera \& Bálint, 2001, which has been considered to be unavailable, or Lamasina Robbins, 2002, a replacement name for Eucharia. A recent re-interpretation of the original description of Annamaria was incorrect, and Annamaria is confirmed as being unavailable under Article 13.1 of the Code. A proposed neotype for Papilio ganimedes Cramer, 1775 is invalidated, and a possible syntype is illustrated. Results of an analysis of variation in the Lamasina ganimedes complex are distinctly different from those previously published and provide insufficient evidence to support the hypothesis that $L$. lathyi (Bálint, 2005) is distinct under a biological species concept. Lamasina lathyi is a synonym of $L$. ganimedes syn. nov. Statistical evidence overwhelmingly falsifies the published hypothesis that the L. rhaptissima (Johnson, 1991) (14 males) and L. columbia (Bálint, 2005) (8 females) species complexes are distinct rather than males and females of the same complex. Lamasina columbia is endemic to western Colombia. The hypothesis that $L$. rhapsodia (Bálint, 2005) from Bolivia is a distinct species is not better supported than the hypotheses that the one known specimen of L. rhapsodia is a geographical variant or an aberrant specimen. Lamasina rhapsodia is a synonym of L. rhaptissima syn. nov. Superficial similarity in ventral wing patterns in genera Paiwarria Kaye, 1904 and Lamasina is noted. A nomenclatural checklist for Lamasina is presented. KEY WORDS. Annamaria, availability of names; columbia; ganimedes; invalid neotype.
\end{abstract}

\begin{abstract}
RESUMO. Nomenclatura, variação e o conceito biológico de espécie em Lamasina (Lycaenidae: Theclinae: Eumaeini). O nome genérico correto para as espécies de Eucharia Boisduval, 1870, um homônimo, é Annamaria D’Abrera \& Bálint, 2001, que tem sido considerado não válido, ou Lamasina Robbins, 2002, um nome substituto para Eucharia. Uma reinterpretação recente da descrição original de Annamaria é considerada incorreta, confirmando a não disponibilidade do nome com base no Artigo 13.1 do Código. O neótipo de Papilio ganimedes Cramer, 1775 é invalidado e um possível síntipo é ilustrado. Os resultados da análise de variação do complexo Lamasina ganimedes diferem significativamente daqueles publicados anteriormente, fornecendo poucas evidências para sustentar a hipótese que L. lathyi (Bálint, 2005) é uma espécie distinta sob o conceito biológico de espécie. Lamasina lathyi é um sinônimo de $L$. ganimedes syn. nov. A evidência estatística falseia categoricamente a hipótese publicada que os complexos de espécies $L$. rhaptissima (Johnson, 1991) (14 machos) e L. columbia (Bálint, 2005) (8 fêmeas) são diferentes e não machos e fêmeas do mesmo complexo. Lamasina columbia é endêmica do oeste da Colômbia. A hipótese de $L$. rhapsodia (Bálint, 2005), da Bolívia, ser uma espécie válida não está tão bem suportada quanto as hipóteses que consideram o único exemplar conhecido da espécie como uma variante geográfica ou um indivíduo aberrante. Lamasina rhapsodia é um sinônimo de L. rhaptissima syn. nov. Foi observada uma semelhança superficial entre os gêneros Paiwarria Kaye, 1904 e Lamasina referente aos padrões das asas em vista ventral. É apresentada uma checklist para Lamasina.
\end{abstract}

PALAVRAS-CHAVE. Annamaria; columbia; disponibilidade de nomes; ganimedes; invalidação de neótipo.

BoIsDuval (1870) described genus Eucharia (Lycaenidae: Theclinae) for three hairstreak butterflies with brilliant green undersides (ganymedes, imperialis, regalis). KIRBY (1871) selected Papilio ganimedes Cramer, 1775 as the type species (ganymedes had been a subsequent misspelling, RobBins \& Lamas 2002), but
SCUDDER (1875) noted that Eucharia Boisduval was a junior homonym of Eucharia Hübner, [1820] and Eucharia Koch, 1835. Although Eucharia Boisduval was consistently cited over the ensuing century (Cомstock \& Huntington 1959-1964, Hemming 1967, Eliot 1973), D’Abrera \& Bálint (2001) did not mention it 
when they transferred $P$. ganimedes to their newly proposed name, Annamaria. Robins (2002) proposed Lamasina as a replacement name for Eucharia Boisduval, placed four species in Lamasina, and explained why Annamaria D'Abrera \& Bálint was unavailable under Article 13.1 of the International Code of Zoological Nomenclature (1999, ICZN hereafter). BÁLINT (2005) disagreed with this taxonomic treatment, presented a new species level taxonomic arrangement based on characters of the wings and androconia, and recognized the name Annamaria as nomenclaturally valid.

The purpose of this paper is to provide evidence that modifies BÁLINT's (2005) nomenclatural and taxonomic conclusions. Specifically, we show that Bálint has proposed nomenclatural changes in Lamasina that do not meet the requirements of the ICzN (1999). We analyze variation in the Lamasina ganimedes species group and show that it is inconsistent with Bálint's species level taxonomy. We present new data on Bálint's L. rhaptissima (all males) and L. columbia (Bálint, 2005) (all females) species groups that falsify Bálint's conclusion that they are separate species groups. Finally, we show that there is yet insufficient evidence on geographical variation to definitively determine biological species in Lamasina, but suggest a provisional classification that better fits current evidence.

\section{MATERIAL AND METHODS}

Wing characters and androconia were examined in 32 males and 28 females of Lamasina (data listed in Appendix I). This sample included: 1) 21 males and 25 females; 2) the types or presumed types of Thecla draudti Lathy, 1926; Thecla godmani Goodson, 1945; Papilio ganimedes Cramer, 1775; Thecla nobilis Herrich-Schäffer, [1853]; Thecla bimaculata Möschler, 1877; and Thecla mirabilis Lathy, 1930; all of which we have examined in person and photographed; and 3) photographs of 6 males and 2 females in various publications (listed in Appendix I), including the types of Annamaria columbia and A. rhapsodia Bálint, 2005. Because BáLINT (2005) differentiated species solely on the basis of wing pattern, wing venation, and androconia, photographs are sufficient to code most characters. BÁLINT (2005) illustrated some types of Lamasina species, and we illustrate the remaining ones (Figs 1-3). The collections from which we examined specimens and their acronyms are: (AME) Florida Museum of Natural History (formerly Allyn Museum of Entomology), University of Florida, Gainesville, FL, USA; (AMNH) American Museum of Natural History, New York, NY, USA; (BMNH) Natural History Museum, London, UK; (CMNH) Carnegie Museum of Natural History, Pittsburgh, PA, USA; (GWB) George W. Busby Collection, Bedford, NH, USA; (JHKW) Jason Hall \& Keith Willmott Collection, Smithsonian Institution, Washington, DC, USA; (MLM) Michael L. McInnis Collection, Floyds Knobs, Indiana, USA; (MNHN) Muséum National d'Histoire Naturelle, Paris, France; (MUSM) Museo de Historia Natural, Universidad Nacional Mayor de San Marcos, Lima, Peru; (RCB) Robert C. Busby Collection, Andover, MA, USA; (RMNH) Nationaal
Natuurhistorische Museum ("Naturalis") [formerly Rijksmuseum van Natuurlijke Historie], Leiden, Netherlands; (SMNS) Staatliches Museum für Naturkunde, Stuttgart, Germany; (USNM) National Museum of Natural History, Smithsonian Institution, Washington, DC, USA; (ZMHB) Museum für Naturkunde der Humboldt-Universität, Berlin, Germany.

Morphological characters were prepared and scored using standard entomological techniques (RobBins 1991), including genitalic dissections and wing slides to score venation characters. Wing vein terminology follows Сомsтоск (1918) except when citing characters verbatim from D'Abrera and BÁLINT (2001). The length of the forewing discal cell was measured from digitized images of wing slides from the base of the forewing to the origin of vein $\mathrm{M}_{2}$. Similarly, forewing length was measured from the base of the forewing to the apex. The presence of ventral forewing "black" androconia was assessed using a binocular microscope. The width of the black portion of the ventral hindwing postmedian line was measured at vein $\mathrm{M}_{2}$ using a stereomicroscope ocular grid for specimens and using a vernier caliper for photographs. We scored the relative widths of black lines on the ventral forewing using BÁLINT's (2005) criterion (conspicuously wider, equal to, or narrower), but had difficulty scoring a number of specimens. Examples of the different character states are illustrated.

In the analysis of variation section, the Neotropics are partitioned into biogeographical areas modified slightly from Brown (1982). The Trans-Andean Region is Mexico to western Ecuador and northwestern Peru, including the Río Magdalena valley of Colombia. The Guiana Region is bounded on the west by a line from the delta of the Río Orinoco (Venezuela) to Manaus (Brazil) and includes the area to the east of this line and to the north of the Amazon River. The Upper Amazon Region consists of those areas west of Manaus (both north and south of the Amazon River) to the eastern slope of the Andes. Species distributions are mapped.

The biological species concept of MAYR (1963) is used except that we do not recognize subspecies for the reasons listed in WiLson \& Brown (1953).

Likelihoods are calculated according to standard statistical techniques (EDWARds 1972).

A summary of the proposed provisional classification is presented in a format similar to that of the previous checklist for the Eumaeini (Robisns 2004b).

\section{Nomenclature}

\section{RESULTS}

\section{Annamaria D’Abrera \& Bálint, 2001}

The original description of Annamaria D'Abrera \& Bálint read "In NEOTROPICAL VII:1107 treated as Evenus draudti. Likewise by other workers. However is distinguished from Evenus by shorter cell of f.w. (1/3rd of costal length), and extension of Vein 1 of h.w. into a lobed tail at tornus. Compound androconial patch on $\sigma^{x}$ f.w. consisting of single circle within cell \& quadri-

Revista Brasileira de Zoologia 25 (1): 116-127, March, 2008 

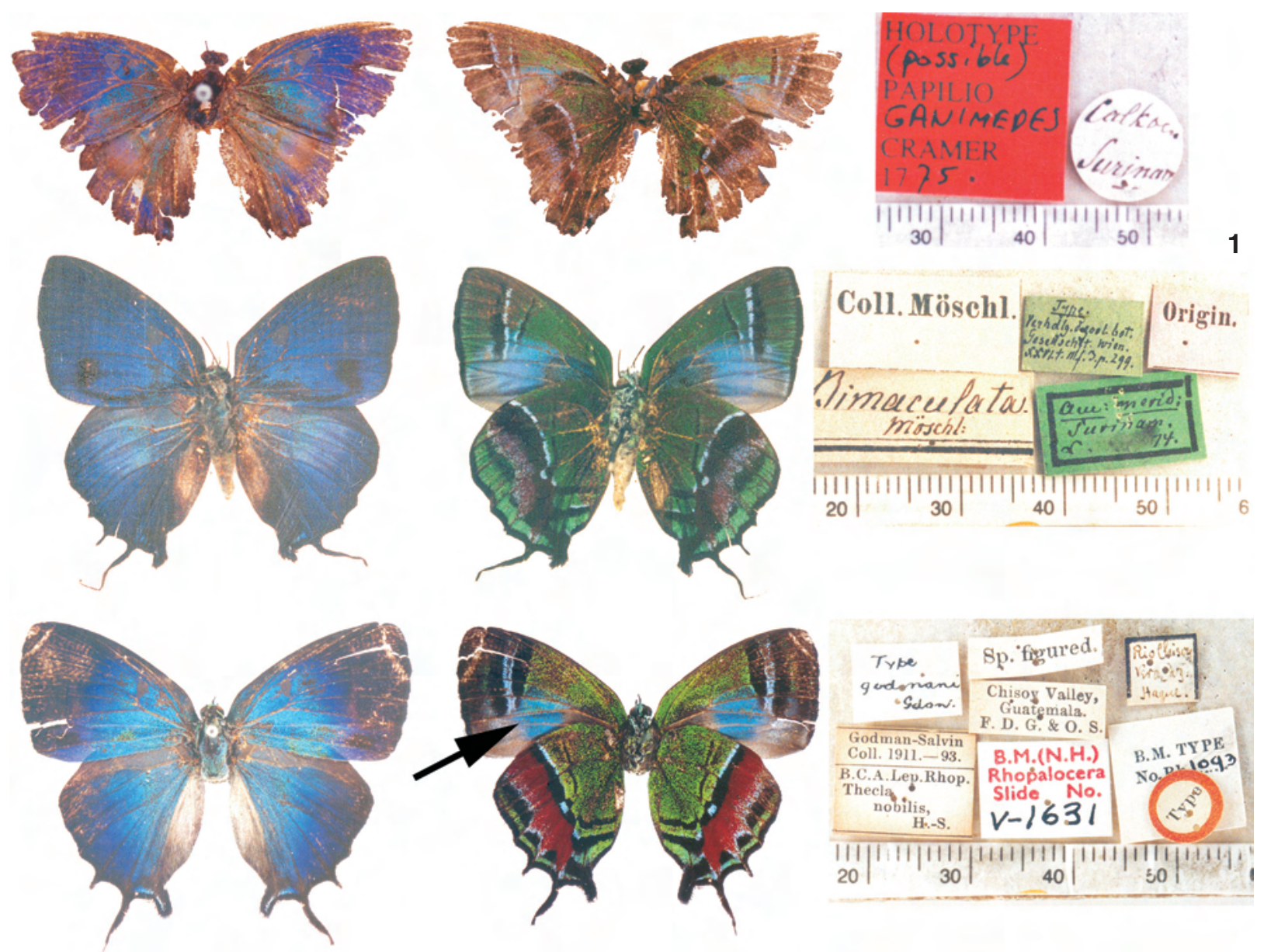

Figures 1-3. Dorsal surface, ventral surface, and labels of three male Lamasina types: (1) the possible holotype of L. ganimedes in RMNH; (2) a male syntype of L. bimaculata in ZMHB; (3) the male holotype of L. godmani in BMNH, the arrow points to blue scales that occur in males of the Lamasina ganimedes complex, but not females.

furcate patch immediately outside discocellulars. Further, androconial patches on post discal \& submarginal tornal areas of f.w. respectively."

RobBINs (2002) noted that Annamaria, D'Abrera \& Bálint, 2001 is unavailable under Article 13.1.1 (ICZN 1999) because the description did not provide "a description or definition that states in words characters that are purported to differentiate the taxon". Rather, the words of the original description differentiate Evenus draudti from Evenus Hübner. In short, the description reads "In NEOTROPICAL VII:1107 [the type species was] treated as Evenus draudti. Likewise [it was so treated] by other workers. However, [it] is distinguished from Evenus by shorter cell of f.w. (1/3rd of costal length), and extension of Vein 1 of h.w. into a lobed tail at tornus. [It has a] compound androconial patch on $\sigma^{x}$ f.w. consisting of single circle within cell \& quadrifurcate patch immediately outside discocellulars. Further, androconial patches on post discal \& submarginal tornal areas of f.w. respectively."
BÁLINT (2005) responded that Annamaria was valid for four reasons. First, he claimed that Robbins "had a subjective intention" in proposing Lamasina as a replacement for Annamaria. Irrespective of its validity, we question whether such a statement belongs in a scientific journal.

Second, Bálint stated that Eucharia Boisduval was a nomen oblitum with a reference to Article 23.9.2 (IcZN 1999). However, designation of a nomen oblitum requires two conditions, one of which is that the junior synonym or homonym - the nomen protectum - had to be used in at least 25 works by at least 10 authors in the preceding 50 years and encompassing a span of not less than10 years. Presumably Bálint considered Annamaria to be the nomen protectum, but it had been used only by D'ABRERA $\&$ BÁLINT (2001). We do not understand this argument.

Third, BÁLINT (2005) argued that Salazaria D'Abrera \& Bálint, 2001 was described in a manner analogous to Annamaria. Since Salazaria was accepted as nomenclaturally valid (RoBbins

Revista Brasileira de Zoologia 25 (1): 116-127, March, 2008 
2004b), Annamaria is nomenclaturally valid also. This argument is incorrect because the description of Annamaria explicitly differentiates Evenus draudti from Evenus while the description of Salazaria does not explicitly differentiate Thecla sala Hewitson - the type species - from Johnsonita Salazar \& Constantino. On the other hand, the description of Salazaria implicitly differentiates Thecla sala and Thecla salaeides Draudt - and not Salazaria - from Johnsonita. Because the nomenclatural validity of Salazaria depends upon interpretation and could generate instability, an application to the International Commission on Zoological Nomenclature is being submitted to stabilize the nomenclature of eumaeine generic names proposed in D'ABRERA \& BÁLINT (2001).

Fourth, BÁLINT stated without evidence that the original description of Annamaria fulfills the requirements of Article 13.1.1 (ICZN 1999). As noted, the words differentiate only the type species. However, the characters in the original description also differentiate only the type species. In fact, with the possible exception of Salazaria, the characters in all their original descriptions characterize only the type species. This finding supports the idea that D'ABrera \& BÁLINT purported to differentiate the type species; it is inconsistent with BÁLINT's contention that they purported to differentiate the genus.

In summary, IczN (1999) Article 13.1 is clear that a new taxon must be "accompanied by a description or definition that states in words characters that are purported to differentiate the taxon". The words in the original description of Annamaria D’Abrera \& Bálint differentiate the type species; they do not differentiate the genus. The characters in the original description distinguish the type species; they do not distinguish the genus. There is no evidence that the authors purported to differentiate Annamaria. The name Annamaria D'Abrera \& Bálint is nomenclaturally unavailable, and we use Lamasina hereafter.

\section{Papilio ganimedes Cramer, 1775}

BÁLINT (2005) designated a neotype for Papilio ganimedes. According to Article 75.3.4 (ICZN 1999), a validly proposed neotype requires "the author's reasons for believing the name-bearing type specimen(s) (i.e. holotype, or lectotype, or all syntypes, or prior neotype) to be lost or destroyed, and the steps that had been taken to trace it or them; ...". In this case, Bálint provided no evidence that he had taken steps to trace a possible syntype. He provided no evidence that syntypes were not extant, only that he believed them to be lost. Therefore, the neotype designation is invalid.

We illustrate a male in RMNH that someone has labeled as a possible holotype of Papilio ganimedes (Fig. 1). It is often difficult to trace old types (LAmas 2007), and we cannot be sure whether or not this specimen is actually a type. However, the wing pattern is reasonably similar to Cramer's figure (illustrated in BÁLINT 2005), it is "set" in the same manner as the original Cramer figure, several of Cramer's types have been found in
RMNH (DE Jong 2005, Chainey 2005), and the potential type is the same species as Bálint's invalid neotype. Identification of the name Papilio ganimedes has posed no problems since LathY (1926) corrected the taxonomy of DraudT (1919-1920), negating the need for a neotype designation.

\section{Taxonomy}

\section{Lamasina Robbins, 2002}

D’Abrera and BÁlint (2001) distinguished Lamasina (under the name Annamaria) by a short forewing discal cell $\left(1 / 3^{\text {rd }}\right.$ of costal length) and by extension of hindwing vein 1 ( = vein $2 \mathrm{~A}$ ) into a lobed tail at the tornus. The first distinguishing trait is problematic. BÁLINT (2005) later reported a forewing discal cell less than $1 / 4^{\text {th }}$ the length of the costa $\left(1 / 6^{\text {th }}\right.$ in males $)$, not $1 / 3^{\text {rd }}$ as originally reported. Further, he measured forewing length to the terminus of vein $\mathrm{R}_{5}$. We presume that Bálint meant vein $\mathrm{R}_{3}$ because the lack of veins $R_{4}$ and $R_{5}$ is a synapomorphy for the Eumaeini (ELIOT 1973). In wing slides of L. draudti, the proposed type species of Annamaria, the length of the discal cell is $35 \%$ of the length of the costa in the male and $41 \%$ in the female (Figs 4-5). The second distinguishing trait is inaccurate for two reasons. First, L. rhaptissima lacks a lobed tail at the tornus. Second, when a lobed tail at the tornus is present, as in L. draudti, hindwing vein 1 ( = vein $2 \mathrm{~A}$ ) does not extend into it (Figs 4-5). In summary, the original description of Annamaria was morphologically incorrect irrespective of its nomenclatural status.

BÁLINT (2005) differentiated Lamasina by a short male forewing discal cell, the form of the androconia on the dorsal forewing, and a lobed "tail" at the hindwing tornus. The first two characters are not unique within the Eumaeini, as BÁLINT (2005) noted. The third is restricted to one species complex within the genus. The closest relatives of Lamasina were not identified. There was no phylogenetic analysis or argument suggesting that any of these characters was a synapomorphy. BÁLINT (2005) noted that the combination of characters is unique.

\section{Analysis of variation the Lamasina ganimedes complex}

We characterize the L. ganimedes complex by an elongate lobe at the tornus (BÁLINT 2005) that is unique within the Eumaeini. Besides the presumed type of L. ganimedes, we illustrate the types of L. godmani and L. bimaculata (Fig. 1); the types of L. nobilis, L. draudti, and L. lathyi were already illustrated (BÁLINT 2005). RobBIns (2004b) recognized L. draudti ( = L. godmani) and L. ganimedes ( = L. nobilis and L. bimaculata) in a checklist, but BÁlint (2005) partitioned this complex into three species ( $L$. draudti, L. ganimedes, L. lathyi) with non-overlapping ranges based on five characters of the wings and androconia. We assess variation of these characters and map their distributions according to our systematic conclusions (Fig. 20).

Bálint character 1. Dorsal forewing with (L. draudti) or without (L. ganimedes, L. lathyi) scent patches in cells $\mathbf{M}_{1}-\mathbf{M}_{2}$ and $\mathbf{M}_{2}-\mathbf{M}_{3}$. Every male in the L. ganimedes complex that we examined (18 males) has dorsal forewing scent patches distal of the disco-cellular veins, including in cells $\mathrm{M}_{1}-\mathrm{M}_{2}$ and 


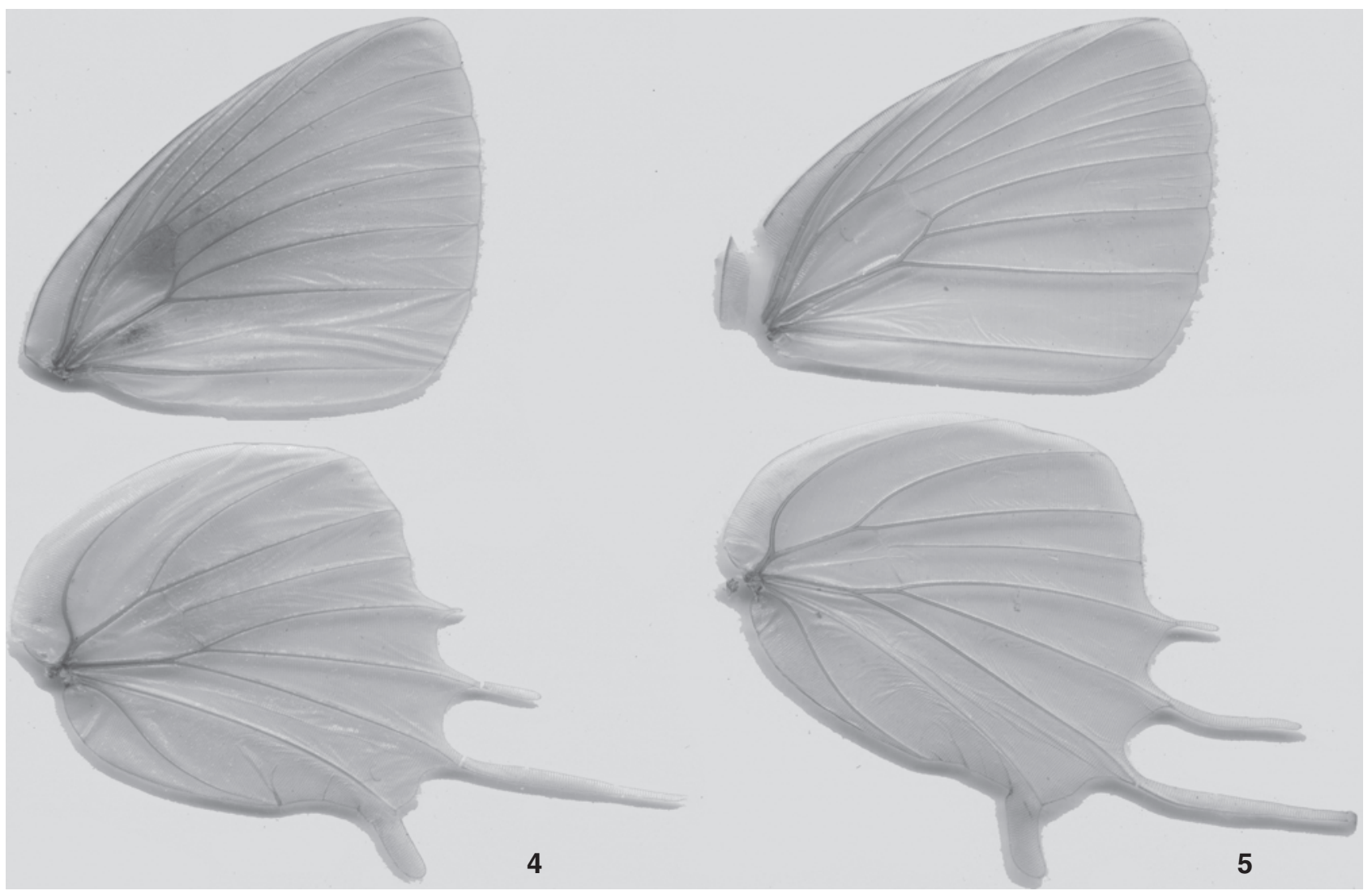

Figures 4-5. Venation of L. draudti: (4) male (Río Carare, Colombia); (5) female (Colombia).

$\mathrm{M}_{2}-\mathrm{M}_{3}$ (Figs 6-7). In the Guiana and Upper Amazon Regions, these androconia are mostly covered with blue wing scales ( 7 males). In the Trans-Andean Region, these androconia are only partially covered with blue scales (11 males), but the extent to which they are covered is variable. This sample includes the Guatemalan holotype of Thecla godmani (Fig. 3), which had been reported to lack these androconia (Goodson 1945).

Bálint character 2. Ventral forewing with distal black band conspicuously wider than ( $L$. draudti), equal to ( $L$. lathyi), or narrower than (L.ganimedes) the more basal black line. In the Trans-Andean Region, the distal black line may be conspicuously narrower than (16 specimens) or about equal in width to (5 specimens) the basal line (Figs 8-9). In the Guiana Region, the distal line may be conspicuously wider than (3 specimens, Figs 1 and 2), about equal to (1 specimen), or narrower than (1 specimen) the width of the basal line. For example, the male of L. ganimedes that BÁLINT (2005) illustrated (his fig. 13) has the lines about equal, and the two females that he illustrated (his figs 15 and 17) have the distal line wider. In the Upper Amazon Region, both lines may be about the same width (11 specimens) or narrower (1 specimen) than the basal line.

Bálint character 3. Ventral hindwing postmedian red band bordered basally with a conspicuous black line ( $L$. draudti) or with a faint or no black line (L. ganimedes and $L$. lathyi). The "red band" ranges in color from red (Fig. 3) to dark maroon to black (Fig. 1), and measurements in the latter case may be somewhat inaccurate. All 21 specimens from the TransAndean Region have a conspicuous black distal edge to the postmedian line at vein $\mathrm{M}_{2}$, ranging from 1.05 to $1.79 \mathrm{~mm}$ wide (Figs 10 and 11). The distal black edge of the postmedian line is less conspicuous at vein $\mathrm{M}_{2}$ in the Guiana and Upper Amazon Regions, ranging from 0 to $0.85 \mathrm{~mm}$ wide (Figs 10 and 11).

Bálint character 4 . Ventral forewing with ( $L$. ganimedes) or without (L. draudti and L. lathyi) a basal black scent patch along the cubital vein. All 18 males that we examined have "black" androconia (under a microscope, the scale color may be tan, gray, or black) near the base of the cubital vein. The androconia are intermixed with regular wing scales, but it is difficult to score the extent of the androconia because the base of the ventral forewing in "set" specimens is covered by the hindwing. In the Guiana Region, the possible type of $L$. ganimedes (Fig. 1) is representative of males with few regular wing scales mixed with androconia at the base of the cubital vein, but the type of Thecla bimaculata is representative of males

Revista Brasileira de Zoologia 25 (1): 116-127, March, 2008 

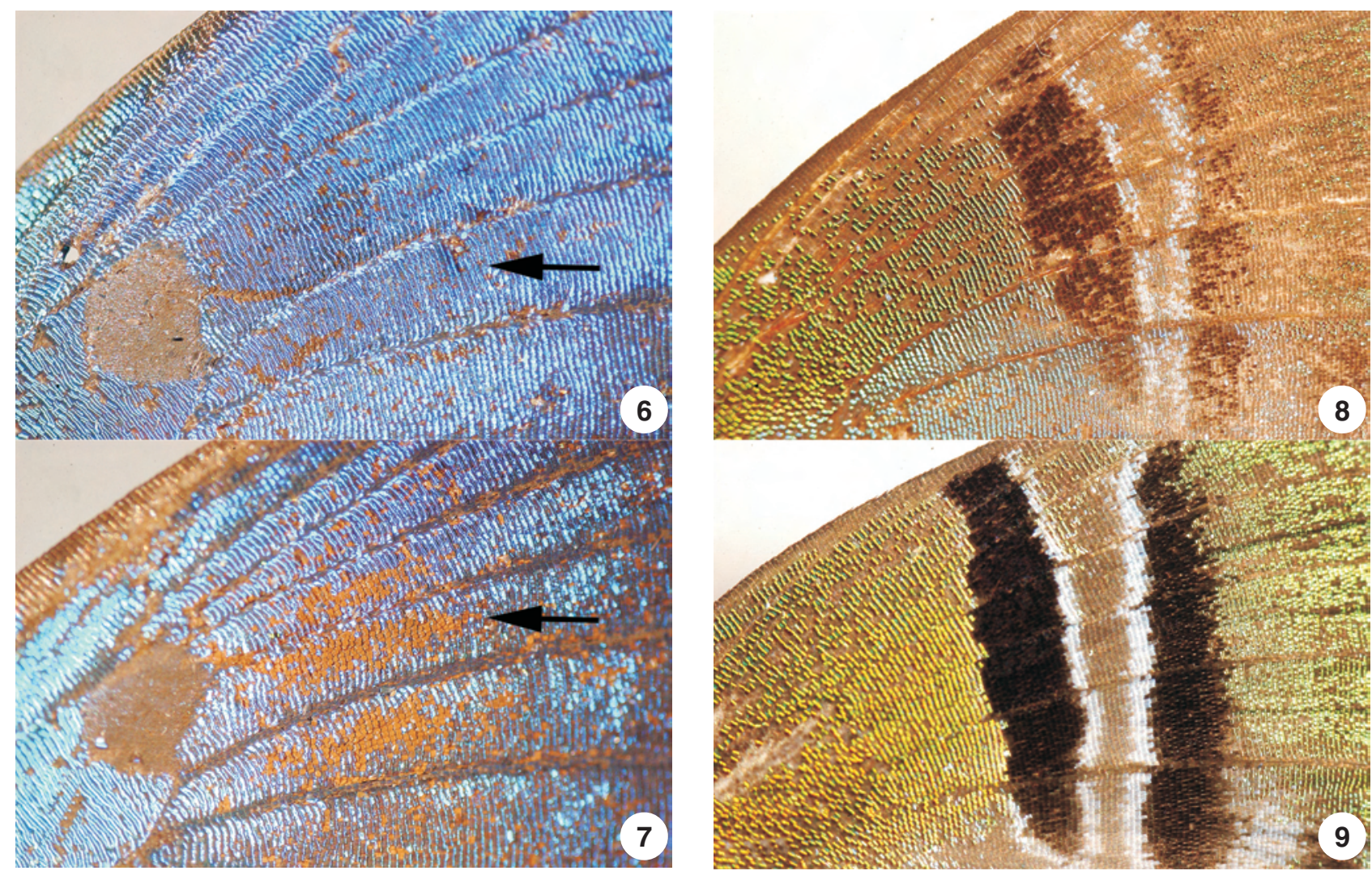

Figures 6-9. (6-7) Dorsal forewing androconia in cells $M_{1}-M_{2}$ and $M_{2}-M_{3}$ (arrows): (6) the darker blue area is androconia covered with blue scales (L. ganimedes, Rio Negro, Meta, Colombia); (7) patches of blue scales covering the androconia are lacking ( $L$. draudti, Guapiles, Costa Rica); (8-9) ventral forewing black bands in female L. draudti: (8) distal band narrower than basal one (Alluriquin, Pichincha, Ecuador); (9) distal band width about the same as the basal band (10 Km E Santo Domingo, Pichincha Ecuador).

in which the androconia are mixed with regular wing scales so that the scent patch is less conspicuous (Fig. 2). In the TransAndean and Upper Amazon Regions, the number of androconia is also variable, some being similar to the type of T. bimaculata (Fig. 3), and others having fewer androconia mixed with regular wing scales (Figs 12 and 13).

Bálint character 5. Dorsal forewing deep (L.ganimedes) or light azure (L. draudti, L. lathyi) color. The hue of iridescent colors varies with angle of view and with lighting conditions (natural, artificial, wavelength, etc). We cannot accurately score this character based on our images of the L. ganimedes complex and can neither confirm nor falsify it.

\section{Lamasina rhaptissima complex}

We examined 14 individuals in the L. rhaptissima species group as characterized by Bálint (males of L. rhaptissima and $L$. columbia in Appendix I). They occur in Andean montane forest between 800 and $1700 \mathrm{~m}$, and have the same arrangement of hindwing tails as males of the L. ganimedes complex, a forewing discal cell about $35 \%$ of the length of the forewing costa as in males of the L. ganimedes complex, and male genitalia almost indistinguishable from those of the L. ganimedes complex (Figs 14 and 15). All 14 individuals are males, and no females have been reported.

We examined eight individuals in the L. columbia species group as characterized by Bálint (females of L. rhaptissima and $L$. columbia in Appendix I). They occur in Andean montane forest between 600 and $1300 \mathrm{~m}$, and have the same arrangement of hindwing tails as females of the L. ganimedes complex, a forewing discal cell about $40 \%$ of the length of the forewing costa as in females of the L. ganimedes complex, and female genitalia indistinguishable from those of the L. ganimedes complex (Figs 16 and 17). All eight individuals are females, and no males are known. The distribution of the L. columbia species group is essentially the same as that of the L. rhaptissima species group. Females of the L. columbia species group were collected at the same two Ecuadorian localities as males of the L. rhaptissima species group (Appendix I), so these species groups are sympatric.

There are two hypotheses, and we ask which one is more likely. The first hypothesis, which was proposed by BÁLINT

Revista Brasileira de Zoologia 25 (1): 116-127, March, 2008 

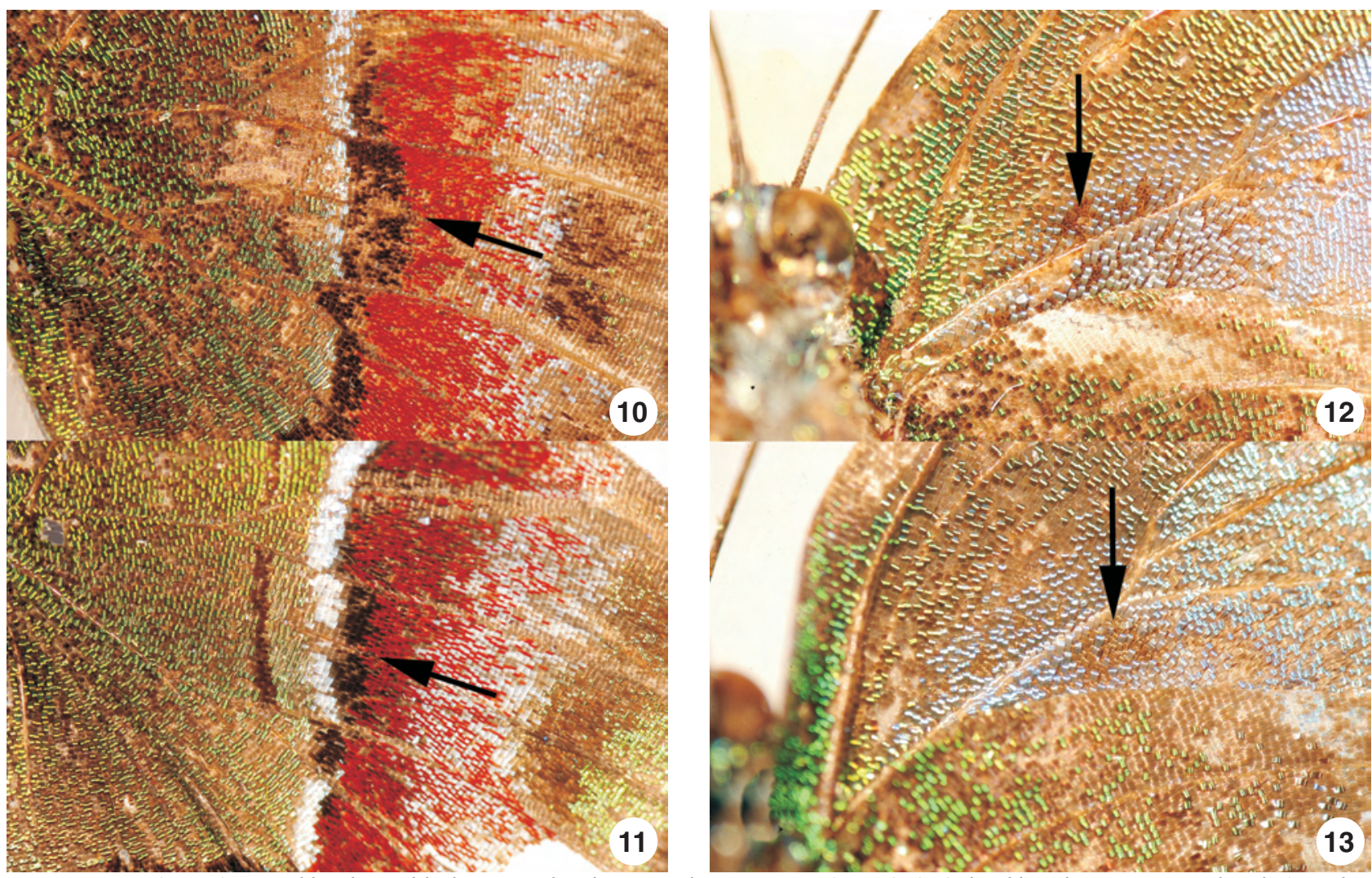

Figures 10-13. (10-11) Ventral hindwing black postmedian line in males at vein $\mathrm{M}_{2}$ (arrow): (10) distal band > $1 \mathrm{~mm}$ in $L$. draudti (Bugaba, Panama); (11) distal band < $1 \mathrm{~mm}$ in L. ganimedes (Rio Negro, Meta, Colombia); (12-13) ventral forewing "black" androconia interspersed among regular wing scales (arrows): (12) L. draudti (Bugaba, Panama); (13) L. ganimedes (25 Km Puyo-Napo Rd, Pastaza, Ecuador).

(2005), is that there are two species complexes, one known from 14 males and one known from 8 females. The alternate hypothesis is that there is one species complex with 14 males and 8 females. Let (p) be the probability of sampling a male and (1-p) the probability of sampling a female. The likelihood that there are two species complexes, one known from 14 males and one known from 8 females, is $(p)^{14} \mathrm{X}(1-\mathrm{p})^{8}$. The likelihood of the alternate hypothesis is $((22 !) /((14 !) \mathrm{x}(8 !))) \mathrm{x}(\mathrm{p})^{14} \mathrm{x}(1-\mathrm{p})^{8}$. The alternate hypothesis is 319,770 times more likely than Bálint's hypothesis (EDwARDs 1972 for methods). In lieu of any evidence to the contrary, we combine these two species complexes as the L. rhaptissima complex.

Assessing variation in the L. rhaptissima complex is difficult because of the paucity of specimens. As with the $L$. ganimedes complex, males have androconia on the dorsal forewing and hindwing (the hindwing androconia were not noted in BÁLINT [2005] although evident in his fig. 18) that are partially covered with blue wing scales (as well as ventral forewing androconia intermixed with regular wing scales along the cubital vein). The extent of the blue scales covering the androconia varies geographically within the L. rhaptissima com- plex, as it does in the L. ganimedes complex. The wing shape of individuals from western Colombia, however, is less "wide" than those from the eastern slope of the Andes (Figs 18 and 19). Further, females from western Colombia, including the mislabeled type of $L$. columbia ("Bogota"), lack the green scales that are prominent at the base of the ventral wings of specimens from the eastern slope of the Andes (Figs 18 and 19). We map the distributions of these phenotypes according to our systematic conclusions (Fig. 21).

BÁLINT (2005) differentiated $L$. rhapsodia from $L$. rhaptissima by darker blue dorsally, a slightly different ventral hindwing pattern, and slightly different dorsal forewing androconia. This species was described from one Bolivian male, so it is not possible to assess the significance of this variation.

\section{DISCUSSION}

Males in the L. ganimedes complex have ventral forewing blue scales (Fig. 3) that do not occur in females, a homoplastic sexual dimorphism that occurs only in the Eumaeus, Brangas, Atlides, and Micandra Sections of the Eumaeini (RobBins 2004a). Robisns (2004a,b) presented no phylogenetic evidence concern-

Revista Brasileira de Zoologia 25 (1): 116-127, March, 2008 

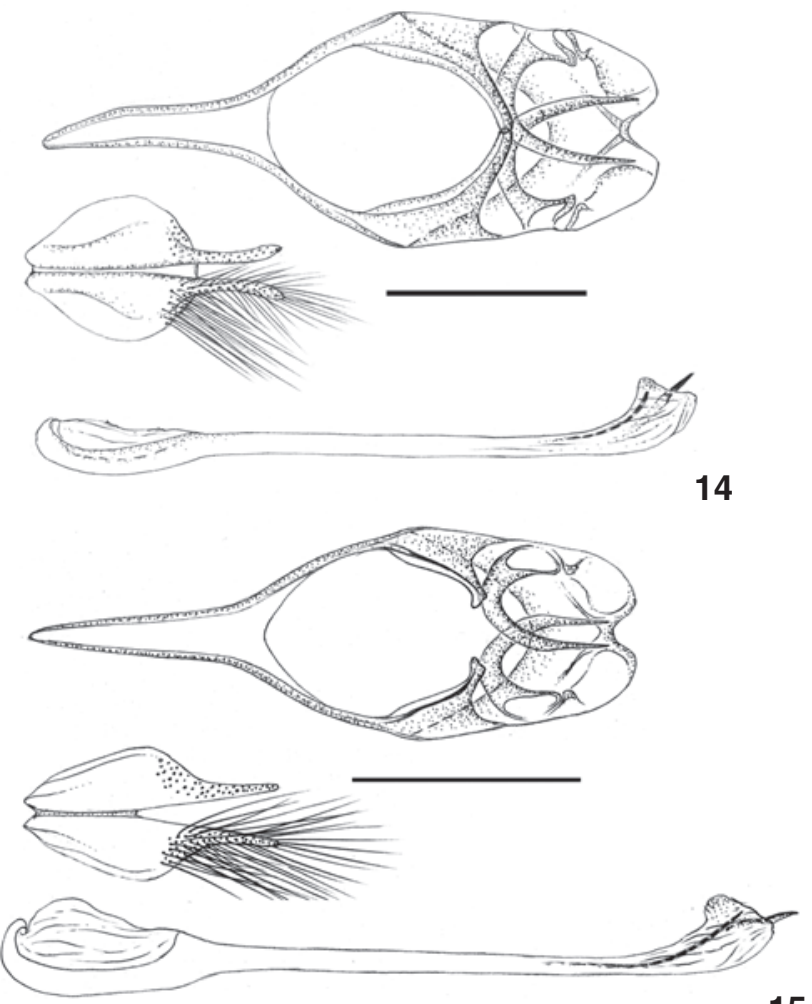

15

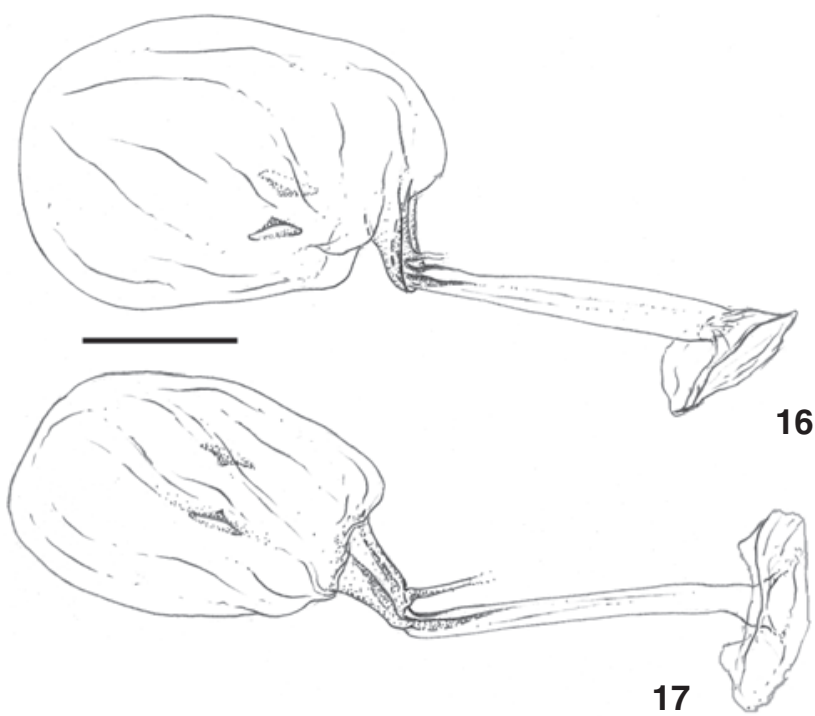

Figures 14-17. (14-15) Male genitalic capsule in ventral aspect (posterior to the right) with valvae separated and penis in lateral aspect: (14) L. draudti ("Bogota", Colombia), (15) L. rhaptissima (Abitagua, Pastaza, Ecuador); (16-17) female genitalia bursa copulatrix in lateral aspect, posterior to the right: (16) L. draudti ("Bogota", Colombia); (17) L. rhaptissima (La Salud, Chanchamayo, Peru). There are semi-membranous "plates" at the posterior end of the ductus bursae that are difficult to illustrate. Scale $1 \mathrm{~mm}$. ing the relations of Lamasina other than that it belongs to one of these Sections. He placed Lamasina next to Evenus because both genera share some wing pattern characteristics, but Lamasina is not otherwise demonstrably related to any other genus, a view first expressed by Godman \& SALvin (1887). BÁLINT's (2005: 119) statement that "RoBbins (2004) suggested Evenus ... as sister group [of Lamasina]" has no basis in fact.

Assessing the monophyly of Lamasina is complicated by not knowing its closest relatives. However, male and female genitalia are exceedingly similar between the L. draudti and $L$. rhaptissima species groups (Figs 14-17), and are different from all other eumaeines (Robbins unpubl.). On this provisional basis, RobBins (2004b) recognized Lamasina as a monophyletic genus. BÁLINT (2005) did not support his recognition of Lamasina with a phylogenetic argument, perhaps because he considers the concept of monophyly to be a threat to taxonomy (BÁLINT 2006). Indeed, the three androconial and wing pattern distinguishing characters proposed by BÁLINT (2005) either occur in other eumaeine genera or do not occur in all Lamasina species. However, when the closest relatives of Lamasina are determined, it is possible that one or more of these characters may be recognized as synapomorphies.

There is insufficient data in the L. ganimedes complex to partition it confidently into species under a biological species concept. Wing pattern and androconial characters are highly variable, as we have documented. It is not known if the "phenotypes" recognized by BÁLINT (2005) are allopatric, parapatric, or sympatric. And if they are sympatric, we do not know if the proposed distinguishing characters gradually intergrade, abruptly intergrade in a narrow geographical band, or do not intergrade. The variation that we document, however, is inconsistent with that reported by BÁLINT (2005) and does not support his taxonomic conclusions. For this reason, we propose a provisional classification that is better supported by evidence.

In the L. ganimedes complex, Trans-Andean Region males have fewer blue scales covering the dorsal forewing androconia (a modification of Bálint Character 1, Figs 6 and 7). Similarly, both sexes from the Trans-Andean Region have a thicker black postmedian line on the ventral hindwing (greater than $1 \mathrm{~mm}$ wide at vein $\mathrm{M}_{2}$ ) than those from the Guiana and Upper Amazon Region (less than $1 \mathrm{~mm}$ wide at vein $\mathrm{M}_{2}$ ) (Bálint Character 3, Figs 10 and 11). We have no evidence to falsify the hypothesis that the Trans-Andean Region specimens represent a distinct species, but admittedly data from the critical geographical area where these phenotypes meet (if they do) are yet lacking. Further, the name $L$. draudti, which applies to these TransAndean specimens, has not previously been treated as a synonym, so far as we are aware. The type of Thecla godmani from Guatemala could represent a distinct species, but with only one individual, it would be premature to remove this name from synonymy with $L$. draudti.

The Upper Amazon phenotype of L. ganimedes, which BáLINT (2005) named L. lathyi, represents either a geographical form of 

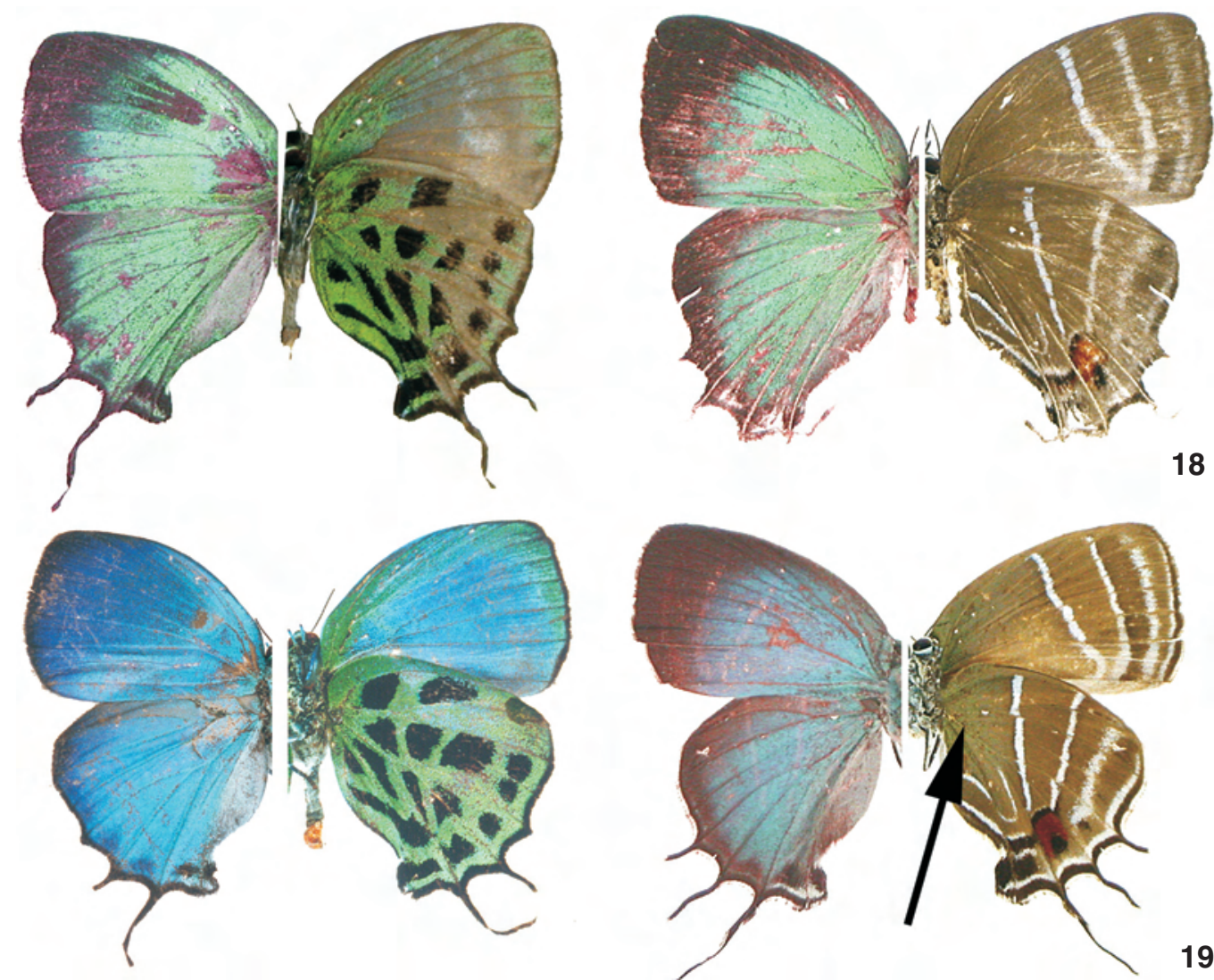

18

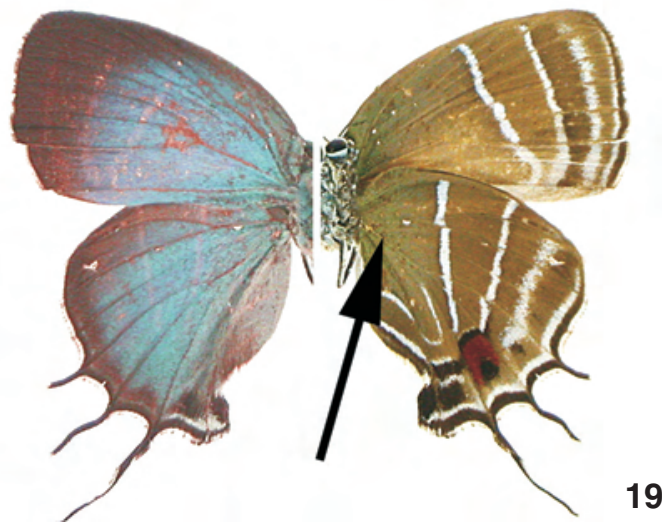

Figures 18-19. Lamasina rhaptissima complex: (18) L. columbia male (Calima Dam, Valle, Colombia) and female (Calima, Valle, Colombia); (19) L. rhaptissima male (eastern Ecuador, the holotype in MNHN) and female (La Salud, Chanchamayo, Peru), arrow points to green scales at the base of the ventral wings.

L. ganimedes or a distinct biological species. None of the evidence proposed by BáLINT (2005) or that we have documented supports the latter hypothesis better than the former hypothesis. Relative widths of the ventral forewing black lines (Bálint Character 2, Figs 8 and 9) are very difficult to score in some individuals and are variable in all geographical regions, contrary to BÁLINT's (2005) results. The extent of the ventral forewing androconia is more pronounced on average in males from the Guiana Region than the Upper Amazon (Bálint Character 4, Figs 1-3 and 12-13), but is not distinguishing. For example, the mixture of androconia and regular wing scales in the male type of Thecla bimaculata (Fig. 2) from the Guiana Region is similar to that of males in other regions (Figs 3 and 12-13). Finally, males from the Guiana Region are darker blue than those from the Upper Amazon (Bálint Character 5), but females cannot be distinguished. We do not know if the blue color of males intergrades where these phenotypes meet, but distinguishing species on this basis is somewhat analogous to partitioning human beings into species based on skin color variation in males. In sum, there is no convincing evidence that the available name $L$. lathyi represents a distinct biological species, for which reason we synonymize it with L. ganimedes syn. nov.
Classification in the L. rhaptissima complex is more tenuous. The green scales at the base of the ventral wings of female L. rhaptissima are lacking in females from western Colombia (Figs 18-19). Both males and females from western Colombiaconsistently and with little variation-have a different wing shape (less wide) than those from the eastern Andes (Figs 1819). There are also other evident differences (Figs 18-19), such as a wider border on the dorsal forewing of males, that provide substantive evidence for reproductive isolation. We recognize the western Colombian phenotype, to which the name $L$. columbia applies, as a distinct species. The single male from Bolivia (L. rhapsodia) may represent a developmental aberration, a clinal geographical form, or a distinct species. BÁLINT (2005) provided no evidence under a biological species concept that better supports the hypothesis that the Bolivian specimen represents a distinct species. For this reason, L. rhapsodia is a synonym of $L$. rhaptissima syn. nov.

The combination of the all-male L. rhaptissima and the all-female L. columbia species groups is intriguing for its potential evolutionary significance. The L. ganimedes complex has traditionally been grouped with the unrelated Paiwarria telemus

Revista Brasileira de Zoologia 25 (1): 116-127, March, 2008 


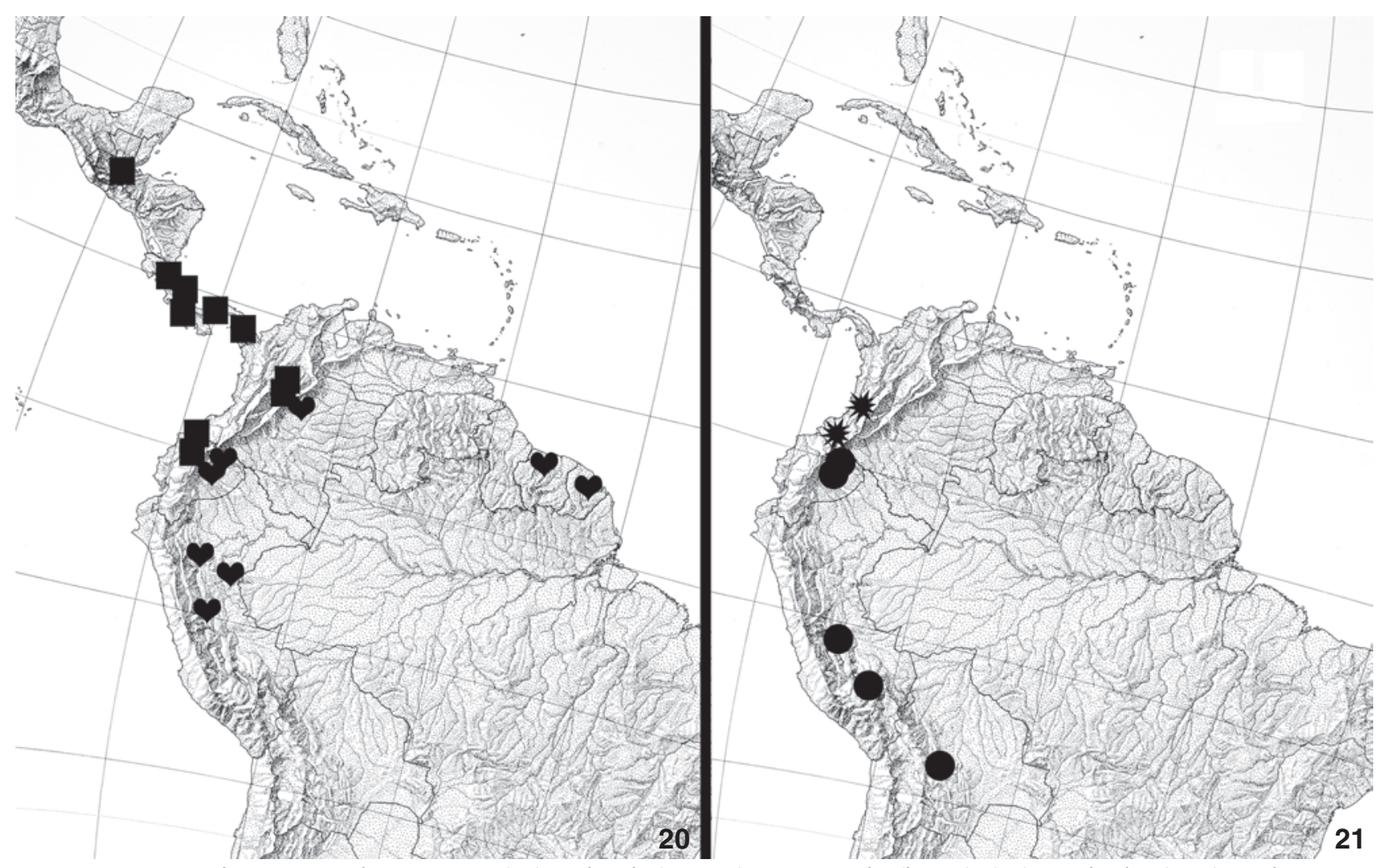

Figures 20-21. Distribution maps for Lamasina: (20) L. draudti (squares), L. ganimedes (hearts); (21) L. columbia (stars), L. rhaptissima (circles). The "hearts" in French Guiana and Surinam represent the country, not specific localities within these countries.

(Cramer, 1775) and P. antinous (C. Felder \& R. Felder) because they have superficially similar ventral wing patterns (i.e., DRAUDT 1919-1920). Two other species of Paiwarria Kaye, 1904, $P$. episcopalis (Fassl) and P. chuchuvia Hall \& Willmott, however, have males with brilliantly iridescent green undersides and thick black bands while the females have gray undersides with long straight white lines (HaLl \& WiLLmotr 2005). This sexual dimorphism in ventral wing pattern mirrors the sexual dimorphism in the L. rhaptissima complex. Unfortunately, these species are so rarely seen in the field that it would be difficult to study this intriguing result.

Roвbins (2004b) tentatively placed Denivia saphonota Constantino, Salazar \& Johnson in Lamasina even though he knew this species only from the original description and illustration. This species was recorded only from females from western Colombia, it had a forewing discal cell length about $40 \%$ of the length of the costa-like females of the L. ganimedes complex-and a male of Lamasina was known from western Colombia (Fig. 18) that at the time did not have an associated female. These reasons were the basis for its placement, but the subsequent discovery of a female Lamasina from western Colombia (Fig. 18) falsifies the original justification of the generic placement in Lamasina.
BÁLINT (2005) transferred D. saphonota to Brevianta Johnson, Kruse \& Kroenlein. He did not note that this species has the same forewing discal cell as females of Lamasina. Rather, he based this action on phenotypic wing similarity and a "membranous large and wide female genital ductus bursae." It is hard to understand this action because the ductus bursae of Brevianta is sclerotized, not membranous. BÁLINT's (2005) transfer may be correct (we have not had the opportunity to dissect a specimen), but the placement of $D$. saphonota remains dubious until accurate character evidence is published.

The following provisional classification summarizes our analysis of variation:

Lamasina Robbins, 2002, nom. nov.

Eucharia Boisduval, 1870, preocc. (Hübner, [1820])

Annamaria D'Abrera \& Bálint, 2001, unavail. (IczN 1999, Art. 13.1)

draudti (Lathy, 1926) (Thecla) - "Central America"; Colombia godmani (Goodson, 1945) (Thecla) - Guatemala

ganimedes (Cramer, 1775) (Papilio) - "West Indies" ganymedes (Fabricius, 1776) (Papilio), missp. - "West Indies" nobilis (Herrich-Schäffer, [1853]) (Thecla) - Surinam bimaculata (Möschler, 1877) (Thecla) - Surinam

Revista Brasileira de Zoologia 25 (1): 116-127, March, 2008 
lathyi (Bálint, 2005) (Annamaria), Syn. nov. - Peru columbia (Bálint, 2005) (Annamaria) - Colombia rhaptissima (K. Johnson, 1991) (Thecla), repl. name - Ecuador mirabilis (Lathy, 1930) (Thecla) - Ecuador preocc. (not Erschoff, 1874)

mirabilissima (D’Abrera, 1995) (Evenus), repl. name Ecuador

rhapsodia (Bálint, 2005) (Annamaria), Syn. nov. - Bolivia

\section{ACKNOWLEDGEMENTS}

We are sincerely grateful to the curators of the museums listed in the methods section for allowing us to gather data over the past three decades from the collections for which they have responsibility. These colleagues have always been graciously helpful. We are indebted to Robert Busby, George Busby, Jason Hall, and Michael McInnis for allowing us to record data from their private collections. We are grateful to Vichai Malikul for rendering the genitalic illustrations. For reading the manuscript repeatedly and making helpful suggestions, we thank Robert Busby, Konrad Fiedler, and an anonymous reviewer. For help of various kinds, we thank our colleagues Mirna M. Casagrande and Marcelo Duarte.

\section{LITERATURE CITED}

BÁLINT, Z. 2005. A review of the Neotropical hairstreak genus Annamaria with notes on further genera (Lepidoptera: Lycaenidae). Annales Historico-Naturales Musei Nationalis Hungarici 97: 115-149.

BÁLINT, Z. 2006. Monophyly, parsimony and stability: threats to taxonomy. Genus 17 (3): 311-315.

Boisduval, J.B.A.D. DE. 1870. Considérations sur des lépidoptères envoyés du Guatemala à M. de l'Orza. Rennes. Oberthür et fils. $1+100$ p.

BRown, K.S. JR. 1982. Historical and ecological factors in the biogeography of aposematic neotropical butterflies. American Zoologist 22 (2): 453-471.

Chainey, J.E. 2005. The species of Papilionidae and Pieridae (Lepidoptera) described by Cramer and Stoll and their putative type material in the Natural History Museum in London. Zoological Journal of the Linnean Society 145: 283-337.

Сомsтоск, J.H. 1918. The wings of insects. Ithaca, The Comstock Publishing Company, 430p.

Comstock, W.P. \& E.I. Huntington. 1959-1964. An annotated list of the Lycaenidae (Lepidoptera: Rhopalocera) of the Western Hemisphere. Journal of the New York Entomological Society 66: 103-118, 67: 59-95, 163-212, 68: 105-122, 176-186, 232-240, 69: 54-58, 105-118, 157-176, 191-200, 70: 39-46, 100-118, 177-179, 71: 45-57, 115-119, 189-197, 262-264, 72: 120-130, 173-192.

D'ABrera, B.L. 1995. Butterflies of the Neotropical region. Part VII. Lycaenidae. Black Rock, Hill House, p. I-XI+1098-1270.
D'Abrera, B.L. \& Z. BÁlint. 2001. Genus Annamaria, Genus Salazaria, p. 194-195. In: B.L. D'ABRERA (Ed.). The concise atlas of butterflies of the world. Melbourne, Hill House Publications, $353 \mathrm{p}$.

DE Jong, R. 2005. Metamorpha sulpitia (Lepidoptera, Nymphalidae) and the vicissitudes of old collections. Entomologische Berichten 65: 124-127.

Draudt, M. 1919-1920. Theclini F., p. 744-812. In: A. Seitz (Ed.). Macrolepidoptera of the World. V. The American Rhopalocera. Stuttgart, Alfred Kernen Verlag, 1139p.

EDWARDS, A.W.F. 1972. Likelihood, an account of the statistical concept of likelihood and its application to scientific inference. London, Cambridge University Press, 235p.

Eliot, J.N. 1973. The higher classification of the Lycaenidae (Lepidoptera): a tentative arrangement. Bulletin of the British Museum (Natural History) (Entomology) 28 (6): 371-505.

Godman, F.D. \& O. SALVIN. 1887. Biologia Centrali-Americana. Insecta. Lepidoptera-Rhopalocera. London, Dulau and Col, Bernard Quaritch, vol. 2, 782p., vol. 3, 112pls.

Goodson, F.W. 1945. Notes and descriptions of new species of American Theclinae contained in the British Museum (Natural History) (Lep. Lycaenidae). Entomologist 78: 169-171, 184-187.

Hall, J.P.W. \& K. R. Willmotт. 2005. A new species of Paiwarria (Lepidoptera: Lycaenidae: Eumaeini) from western Ecuador. Proceedings of the Entomological Society of Washington 107 (4): 960-967.

Hemming, F. 1967. The generic names of the butterflies and their type-species (Lepidoptera: Rhopalocera). Bulletin of the British Museum (Natural History) (Entomology), Supplement 9: 1-509.

ICZN. 1999. International Code of Zoological Nomenclature. London, The International Trust for Zoological Nomenclature, $4^{\text {th }}$ ed., $306 \mathrm{p}$.

KIRBY, W.F. 1871. A synonymic catalogue of diurnal Lepidoptera. London, John Van Voorst, VII+690p.

LAMAs, G. 2007. Invalidation of six neotypes among Neotropical butterflies (Lepidoptera: Hesperiidae, Pieridae, Lycaenidae and Nymphalidae). Revista Peruana de Entomología 45: $115-119$

Lathy, P.I. 1926.Notes on the American Theclinae (Lepidoptera). Annals and Magazine of Natural History 17 (9): 35-47.

MaYr, E. 1963. Animal species and evolution. Cambridge, Belknap Press of Harvard University Press, 797p.

Robisns, R.K. 1991. Evolution, comparative morphology, and identification of the eumaeine butterfly genus Rekoa Kaye (Lycaenidae: Theclinae). Smithsonian Contributions to Zoology 498: 1-64.

Roвbins, R.K. 2002. Replacement names in the Eumaeini (Lepidoptera: Lycaenidae: Theclinae). Proceedings of the Entomological Society of Washington 104: 820-821.

Roвbins, R.K. 2004a. Introduction to the checklist of Eumaeini 
(Lycaenidae), p. xxiv-xxx. In: LAMAs, G. (Ed.). Checklist: Part 4A. Hesperioidea - Papilionoidea. In: J.B. Heppner (Ed.). Atlas of Neotropical Lepidoptera. Gainesville, Association for Tropical Lepidoptera; Scientific Publishers, vol. 5A.

Robins, R.K. 2004b. Lycaenidae. Theclinae. Tribe Eumaeini, p. 118-137. In: LAMAS, G. (Ed.). Checklist: Part 4A. Hesperioidea - Papilionoidea. In: J.B. Heppner (Ed.). Atlas of Neotropical Lepidoptera. Gainesville, Association for Tropical Lepidoptera; Scientific Publishers, vol. 5A.

Robbins, R.K. \& G. LAmas. 2002. Nomenclatural Changes in the Neotropical Eumaeini (Lepidoptera, Lycaenidae, Theclinae).
Revista Brasileira de Zoologia 19: 197-214.

SALAzAR, J.A. 1993. Noticias sobre seis raras especies de licénidos colombianos. Descripción de una nueva especie de Riodininae para Colombia (Lepidoptera: Lycaenidae). Shilap 21 (81): 47-53.

ScUdDER, S.H. 1875. Historical sketch of the generic names proposed for butterflies: a contribution to systematic nomenclature. Proceedings of the American Academy of Arts and Sciences 10: 91-293.

Wilson, E.O. \& W.L. Brown JR. 1953. The subspecies concept. Systematic Zoology 2: 97-111.

Appendix I. Specimens Examined. Those localities in quotation marks are undoubtedly incorrect. The species names are those recognized in this paper. The biogeographic regions are described in the text. The distributions are mapped except for those in quotation marks (Fig. 10).

Lamasina draudti (Lathy). [Trans-Andean Region] Guatemala: 1 male Chisoy Valley [holotype Thecla godmani Goodson] (BMNH). Costa Rica. 1 male Guápiles (USNM), 1 male Carrillo (USNM), 1 female Heredia, La Selva (USNM). Panama: 1 male Bugaba (USNM), 1 male Cerro Campana (USNM), 1 female Cana (USNM), 1 female Altos de Pacora (USNM). W. Colombia: (including Magdalena Valley). 1 male "Bogota" (USNM), 1 male and 1 female Río Carare (USNM), 1 male "Bogota" [lectotype of Thecla draudti Lathy] (MNHN), 1 male Muzo (illustrated in Bálınt 2005), 1 female no further data (USNM), 1 female "Bogota" (USNM), 1 male and 1 female (AMNH). W. Ecuador: 1 male km 5 Lita-Alto Tambo (JHKW), 1 female Alluriquín (USNM), 1 female 12 km E Sto Domingo (USNM), 1 female Río Mira (JHKW). Mislabeled: 1 female Santa Catarina [Brazil] (USNM).

Lamasina ganimedes (Cramer). [Upper Amazon Region] E. Colombia: 2 males Meta, Río Negro (USNM), 1 female Villavicencio (USNM). E. Ecuador: 1 male KM 25 Puyo-Napo Rd (USNM), 1 male and 1 female Sucumbíos, Cerro Lumbaqui Norte (JHKW), 1 female Sucumbíos, 0.5 km SW Lumbaqui (USNM). Peru: 1 female Tingo María (USNM), 2 females Tingo María (MUSM), 1 female alto Río Contaya (MUSM), 1 female Tarapoto-Yurimaguas (MUSM). [Guiana Region] French Guiana: 1 female (illustrated in BÁLINT 2005). Surinam: 1 male no further data [possible syntype Papilio ganimedes Cramer] (RMNH), 1 female no further data [lectotype Thecla nobilis Herrich-Schäffer] (SMNS), 1 male no further data [holotype Thecla bimaculata Möschler], (ZMHB). Guyana: 1 male Junantins (illustrated in BÁLINT 2005, this locality is a mystery to us, but could possibly refer to Tonantins in Amazonas, Brazil.).

Lamasina columbia (Bálint). Colombia: 1 male Valle, Calima Dam, 800m (USNM); 1 female Valle, Calima, 1200m (AME); 1 male Nariño, La Planada, 1700m (illustrated in SALAzAR 1993); 1 female "Santa Fé de Bogotá" [holotype Annamaria columbia] (illustrated in BÁLINT 2005).

Lamasina rhaptissima (Johnson). Ecuador: 1 male Rio Pastazza [sic] [holotype Thecla mirabilis Lathy] (MNHN); 1 male Pastaza, Abitagua, 1300m (AMNH); 3 males and 2 females Pastaza, 25 KM N Puyo, 1000m (GWB, MLM); 1 male Pastaza, 32 KM S Puyo, 1000m (GWB); 2 males and 1 female Tungurahua, Río Topo, 1300m (RCB); 1 female Sucumbíos, Cerro Lumbaqui Norte, 9001000m (RCB); 1 female Napo, Rio Pimpilala (SW of Talag), 600-900m.[RCB]. Peru: 1 male "Iquitos" (MUSM); 1 male Cuzco, Marcapata, Caradoc, 4000 ft (listed in D'Abrera 1995 and BÁLINT 2005 from Ecuador); 1 male Junín, Chanchamayo (illustrated in BÁLINT 2005); 1 female Junín, Chanchamayo, La Salud, 1300m (CMNH). Bolivia: 1 male Potosí, Río Limatambo, 1600 m [holotype Annamaria rhapsodia] (illustrated in BÁLINT 2005).

Received in 11.IX.2007; accepted in 23.II.2008. 